to the abomasum. However, in the ruminant calf the proportion found in the rumen seems to increase with age, particularly beyond one year. The efficiency of the closure of the oesophageal groove does not appear to be determined by the chemical nature of the liquid feed, according to the results obtained with lambs by Orskov, Benzie and KAY (1970) and RuCKEBUSCH and KAY (197I).

\title{
INFLUENCE DE LA COAGULATION DES PROTÉENES SUR LA VIDANGE STOMACALE CHEZ LE VEAU PRÉRUMINANT
}

\author{
J. FRANTZEN, R. TOULlEC, P. THIVEND * et C. M. MATHIEU
}

\author{
Station de Recherches zootechniques, \\ Centre de Recherches de Rennes, I. N. R. A., \\ 65, rue de Saint-Brieuc, \\ 35042 Rennes Cedex \\ * Station de Recherches sur l'Élevage des Ruminants \\ Centre de Recherches de Clermont Ferrand, I. N.R. A., \\ Theix, 63110 Beaumont
}

En remplaçant en totalité les protéines du lait écrémé par celles du lactosérum, nous avons observé une accélération importante de la vidange stomacale des protéines et des lipides (ToulLeC, Thivend et Mathiev, I97 I). A fin de voir si cette accélération était due à l'absence de coagulation ou à l'origine des protéines, nous avons étudié les effets, sur la vidange stomacale, de la modification ou de la suppression de la coagulation des protéines du lait écrémé d'une part, de leur remplacement total par celles des levures d'alcanes (70 p. Ioo) et du lactosérum (30 p. Ioo) d'autre part.

Deux veaux préruminants (A et $B$ ) ont été munis de 2 canules d'ASH placées immédiatement après le pylore. Le veau $\mathrm{A}$ a reçu successivement pendant 4 périodes de 2 semaines un lait de remplacement témoin contenant $68 \mathrm{p}$. Ioo de poudre de lait écrémé (Spray) par rapport à la matière sèche, deux laits de remplacement expérimentaux obtenus en ajoutant au précédent du citrate de sodium ou de l'acide chlorhydrique et un lait de remplacement expérimental dépourvu de lait écrémé et contenant $25 \mathrm{p}$. Ioo de levures d'alcanes, $50 \mathrm{p}$. Ioo de lactosérum et $22 \mathrm{p}$. 100 de matières grasses par rapport à la matière sèche. Le veau $B$ a reçu successivement pendant 3 périodes de 2 semaines un autre lait de remplacement témoin contenant environ 65 p. Ioo de poudre de lait écrémé par rapport à la matière sèche et deux laits de remplacement expérimentaux obtenus en ajoutant au précédent du citrate de sodium ou de l'acide chlorhydrique. In vitro, les aliments témoins formaient rapidement un coagulum ferme sous l'action de la présure. Les aliments "citrate " ( $13,3 \mathrm{~g}$ de citrate de sodium $/ \mathrm{kg}$ de matière sèche) ne coagulaient plus sous l'action de la présure mais pouvaient encore le faire sous l'action de l'acide chlorhydrique. Les aliments " acide " (39 $\mathrm{g} \mathrm{d}$ ' $\mathrm{HCl} \mathrm{pur} / \mathrm{kg}$ de matière sèche - $\mathrm{pH} 4,25$ ) étaient remis en suspension très fine par agitation énergique et ni l'addition de présure ni celle d'acide chlorhydrique ne pouvaient, in vitro, modifier leur état. Lors des prélèvements, les effluents gastriques ont été recueillis en totalité pendant 7 heures consécutives après le repas du matin ; ils ont été simultanément réintroduits dans le duodénum, après prélèvements d'échantillons représentatifs destinés aux analyses.

Chez le veau A, I, 3, 4 et 4 journées de prélèvement ont eu lieu respectivement avec les aliments témoin, citrate, acide et levures. La vidange stomacale de la matière fraîche et de la matière 
ET LA BIOCHIMIE DE LA DIGESTION

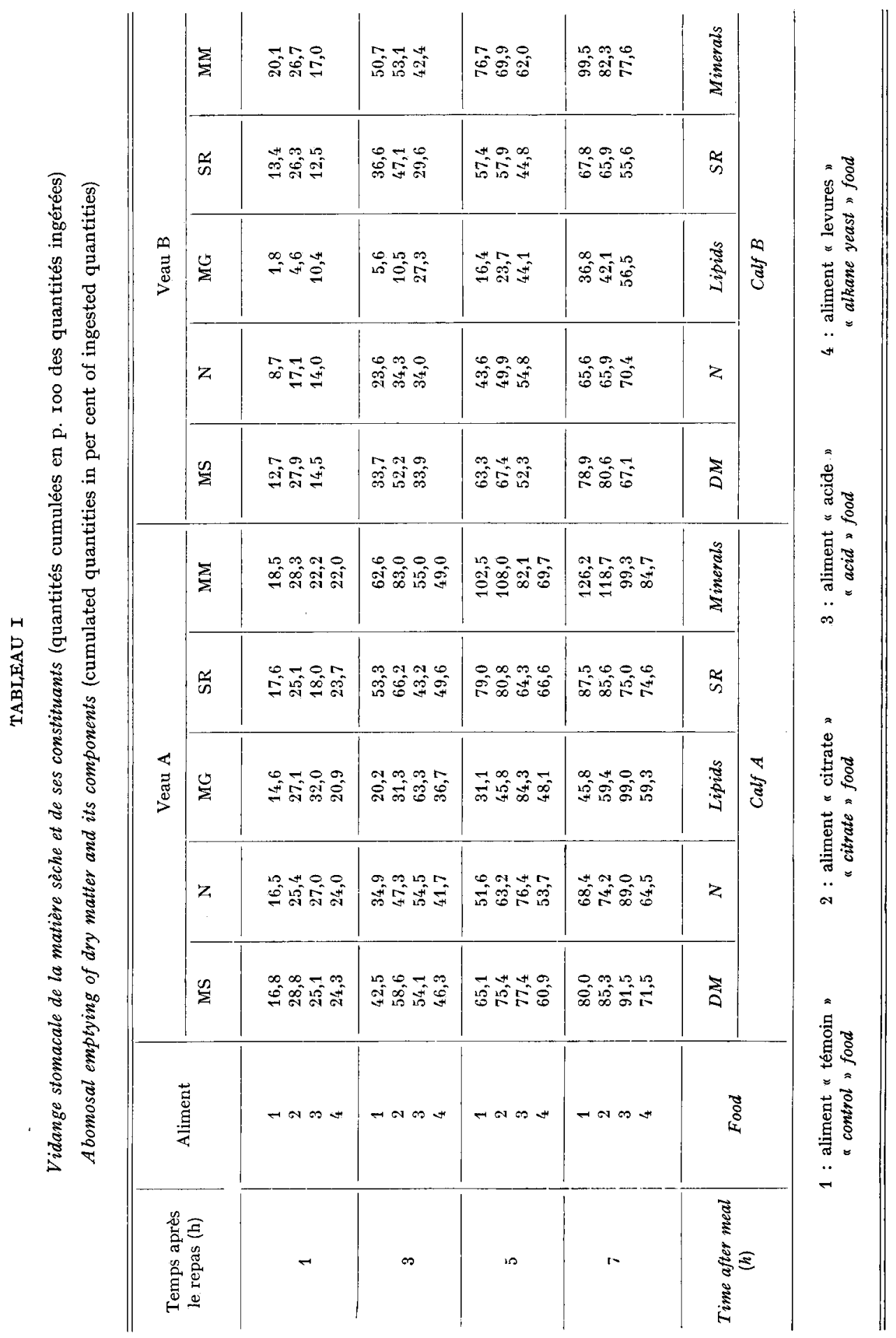


sèche a été un peu plus rapide avec les 3 aliments expérimentaux au cours de la Ire heure après le repas (tabl. I). Dans le même temps, la sortie de tous les constituants de la matière sèche a été légèrement accélérée, sauf celle des substances réductrices avec l'aliment acide : les quantités totales de protéines émises ont atteint respectivement $77,25,27$ et 24 p. Ioo des quantités ingérées. Sur l'ensemble des 7 heures de mesure, les quantités totales de protéines émises ont été de $68,74,89$ et $65 \mathrm{p}$. roo des quantités ingérées.

Chez le veau $\mathrm{B}, 3,4$ et 4 journées de prélèvement ont eu lieu respectivement avec les aliments témoin, citrate et acide. La vidange stomacale de la matière fraîche et de la matière sèche a été un peu plus rapide avec l'aliment citrate au cours de la Ire heure après le repas (tabl. I). Dans le même temps la sortie des protéines, des lipides et des matières minérales a été accélérée avec l'aliment citrate; la sortie des protéines et des lipides a été accélérée et celle des matières minérales ralentie avec l'aliment acide, mais toutes ces différences ont été peu importantes : les quantités totales de protéines émises ont ainsi atteint Io, 17 et 14 p. Ioo des quantités ingérées. Sur l'ensemble des 7 heures de mesures, les quantités totales de protéines émises ont été de 66 , 66 et $70 \mathrm{p}$. Ioo des quantités ingérées.

En conclusion, la modification ou la suppression de la coagulation des protéines du lait, ainsi que leur remplacement par celles des levures d'alcanes (7o p. IO०) et du lactosérum (3० p. IOo) accélèrent généralement la vidange stomacale des protéines et des lipides ; cependant, cette accélération est relativement limitée et demeure beaucoup moins importante que celle que nous avions observée en remplaçant les protéines du lait par celles du lactosérum. Il semble donc que la vidange stomacale soit influencée au moins autant par l'origine des protéines et par la technologie de leur préparation que par la coagulation dans la caillette.

\section{RÉFÉRENCE BIBLIOGRAPHIQUE}

R. Toullec, P. Thivend, C. M. Mathieu, 197r. Utilisation des protéines du lactosérum par le veau préruminant à l'engrais. I. Vidange stomacale comparée du lait entier et de deux laits de remplacement ne contenant que des protéines de lactosérum comme source de matières azotées. Ann. Biol. anim. Bioch. Biophys., 11, 435-453.

\section{SUMMARY}

\section{THE INFLUENCE OF PROTEIN CLOTTING ON ABOMASAI, EMPTYING} IN THE PRERUMINANT CALF

Earlier experiment showed that total replacement of milk proteins by whey proteins increased the rate of abomasal emptying of nitrogen and lipids (Toullec, Thivend and Mathieu, I97I). In order to determine if this acceleration was due to the clotting unability or to the source of proteins, we have studied the influence on abomasal emptying of altering or suppressing the clotting ability of milk proteins and of their replacement by alkanes grown yeasts (70 p. roo) and whey (30 p. I00) proteins.

Two preruminant calves (A and B) were fitted with a duodenal reentrant cannula placed immediately distal to the pylorus. Over 4 periods of 2 weeks, calf A was offered successively a normal milk replacer containing $68 \mathrm{p}$. Ioo spray dried skim milk powder as related to dry matter. Two experimental diets obtained by addition of sodium citrate or hydrochloric acid to the normal diet and another experimental diet without skim milk and containing $25 \mathrm{p}$. Ioo alkanes grown yeasts, 50 p. Ioo whey and 22 p. Ioo fat as related to dry matter. Over 3 periods of 2 weeks, calf B 
was offered successively another normal diet containing $65 \mathrm{p}$. Ioo skim milk powder and two experimental diets obtained by addition of sodium citrate or hydrochloric acid to the normal diet. In vitro, the normal diets gave quickly a firm curd with rennet. The "citrate diets " (13,3 $\mathrm{g}$ sodium citrate/kg dry matter) gave no curd with rennet but could clot with hydrochloric acid. The " acid diets" (39 g pure $\mathrm{HCl} / \mathrm{kg}$ dry matter - $\mathrm{pH} 4$,25) were submitted to a strong agitation and did not clot with rennet nor hydrochloric acid. During 7 consecutive hours after the morning feeding, gastric effluents were completely collected; they were simultaneously re-introduced into the duodenum after representative samples were taken for analysis.

In calf A, I, 3 et 4 collecting days took place respectively with the normal, citrate, acid and yeast diets. Abomasal emptying of fluid and dry matter was a little quicker with the experimental diets during the first hour after the feeding (table $r$ ). The outflow of all the dry matter constituents was also slightly greater, except for reducing substances with the acid diet : I7, 25, 27 and $24 \mathrm{p}$. Ioo respectively of the ingested nitrogen left the abomasum. Over the total of 7 hours of measurements, the cumulative outputs of nitrogen reached $68,74,89$ and 65 p. roo of the ingested amounts.

In calf B, 3, 4 and 4 collecting days took place respectively with the normal, citrate and acid diets. Abomasal emptying of fluid and dry matter was a little quicker with citrate diet during the first hour after the feeding (table $\mathrm{I}$ ). The outflow of nitrogen, fat and minerals was also greater with the citrate diet, the outflow of nitrogen and fat was greater and that of minerals lower with the acid diet, but all these differences were not very important : Io, I7 and $\mathbf{4} 4 \mathrm{p}$. Ioo respectively of the ingested nitrogen left the abomasum. Over the total of 7 hours of measurements, the cumulative outputs of nitrogen reached 66,66 and $70 \mathrm{p}$. 100 of the ingested amounts.

Therefore, the alteration or suppression of the clotting ability of milk proteins, and their replacement by those of alkanes grown yeasts (70 p. 100) and of whey ( $30 \mathrm{p}$. 100) increase the rate of abomasal emptying of nitrogen and fat; however, this acceleration is relatively restricted and stays less important than that observed with milk replacers containing only whey proteins as source of nitrogen. It appears that abomasal emptying is influenced at least as much by the source of proteins and the technology of their preparation as by the clotting in the abomasum.

\title{
ÉTUDE DU RÉSIDU STOMACAL APRÈS 15 H DE JEÛNE CHEZ LE PORC EN CROISSANCE
}

\author{
Geneviève CHARLET-LÉRY, Y. RUCKEBUSCH* et Marie-Thérèse MOREL \\ Laboratoive de Recherche sur la Conservation et l'Efficacité des Aliments, \\ Centre national de Recherches zootechniques, I. N.R. A., \\ 78350 Jouy en Josas \\ * Laboratoire de Physiologie, \\ École nationale Vétérinaire, I. N.R.A., \\ 31076 Toulouse
}

Des études antérieures nous ont montré que le comportement physiologique du porc était fortement perturbé après l'ingestion d'un repas d'une richesse azotée inhabituelle : en particulier, nous avions, sur deux animaux, noté un ralentissement de l'activité électrique très nette dans la région du pylore, moins marqué dans la zone duodénale. Pour vérifier si de telles variations étaient 